\title{
ANALISIS ZONA NILAI TANAH TERHADAP RENCANA TATA RUANG WILAYAH RUNGKUT UNTUK MENINGKATKAN PENDAPATAN DAERAH DI SURABAYA
}

\author{
Udiana Wahyu Deviantari ${ }^{1}$, Andi Nurul W. P. ${ }^{2}$, Andy Dediyono ${ }^{3}$ \\ 1,2Departemen Teknik Geomatika, FTSLK-ITS, Kampus ITS Sukolilo, Surabaya, 60111, Indonesia \\ ${ }^{3}$ Masyarakat Profesi Penilai Indonesia (MAPPI) \\ e-mail: ${ }^{1}$ dianada87@gmail.com
}

\begin{abstract}
Abstrak
Surabaya adalah kota terbesar kedua di Indonesia. Karena itu, banyak warga yang pergi ke kota ini untuk mendapatkan pekerjaan alih-alih bekerja di kota asal mereka. Namun, karena urbanisasi yang pasif itu membuat kebutuhan masyarakat akan rumah semakin besar sementara ketersediaan lahan terbatas. Ketika permintaan tanah lebih tinggi dari tanah yang tersedia maka harga tanah akan lebih tinggi. Dua sumber pendapatan lokal adalah PBB (Pajak Bumi dan Bangunan) dan BPHTB (Bea Perolehan Hak Atas Tanah dan Bangunan) di mana pengimporan dasarnya adalah NJOP (Nilai Jual Objek Pajak) untuk PBB dan NPOP untuk BPHTB. Namun, dalam hal ini NPOP (Nilai Perolehan Objek Pajak) disamakan dengan NJOP karena sumber pendapatan pajak yang sama yaitu komparatif penjualan. Asesmen massa digunakan dalam penelitian ini dengan pertimbangan lokasi memiliki luas wilayah. Oleh karena itu, zona nilai tanah harus ditumpang tindih dengan rencana tata ruang terperinci untuk menghitung potensi pendapatan PBB dan BPHTB. Zona industri memiliki kesesuaian lahan tertinggi $99,22 \%$ dengan luas 857.121.718 m2. Peningkatan pendapatan lokal melalui potensi pendapatan PBB dan BPHTB menunjukkan angka positif atau peningkatan nilai di setiap zona.
\end{abstract}

Kata kunci: Kesesuaian Lahan, Pajak Bumi dan Bangunan, Zona nilai tanah

\begin{abstract}
Surabaya is the second biggest city in Indonesia. For that reason, many citizens are going to this city to get some jobs instead of working in their hometown. However, due to that massive urbanization make people needs of house to live getting bigger while land availability is limited. When the demand for land is higher than the available land then land prices will go higher. Two sources of local revenue are PBB (Property Tax) and BPHTB (Fees for Acquisition of Land and Building Rights) where the basic imposition of them are NJOP (Tax Object Selling Value) for PBB and NPOP (Value of Tax Object Obtaining) for BPHTB. Yet, in this case NPOP is equated with NJOP because of the same source of tax income that is sales comparative. Mass assessment is used in this research in consideration of the location has wide area. Therefore, land value zones must be overlaid against detailed spatial plan to calculate potential income of $P B B$ and BPHTB. The industrial zone has the highest land suitability of $99,22 \%$ with an area of $857.121,718 \mathrm{~m}^{2}$. Increasement of local revenue through the potential income of PBB and BPHTB shows a positive number or increasing value in every zone.
\end{abstract}

Keyword: Land Suitability, Property Tax, Land Value Zone 


\section{Pendahuluan}

Surabaya merupakan kota terbesar kedua di Indonesia. Oleh karena itu, banyak penduduk luar Kota Surabaya pergi ke kota ini untuk memperoleh pekerjaan dibandingkan bekerja di tempat asal mereka. Namun, banyaknya penduduk yang dating membuat kebutuhan akan rumah sebagai tempat tinggal menjadi semakin besar sedangkan ketersediaan tanah begitu terbatas. Jika permintaan tanah lebih tinggi dibandingkan ketersediaan tanah maka harga tanah akan menjadi semakin tinggi.

Pendapatan Asli Daerah adalah pendapatan daerah yang bersumber dari hasil pajak daerah, hasil retribusi daerah, hasil pengelolaan kekayaan daerah yang dipisahkan, dan lain-lain pendapatan asli daerah yang sah. Dua sumber Pendapatan Asli Daerah Kota Surabaya diantaranya adalah PBB (Pajak Bumi dan Bangunan) dan BPHTB (Bea Perolehan Hak Atas Tanah dan Bangunan). Dasar pengenaan untuk PBB adalah NJOP (Nilai Jual Objek Pajak) sedangkan pada BPHTB adalah NPOP (Nilai Perolehan Objek Pajak). Dalam penelitian ini NJOP dan NPOP disamakan karena berasal dari sumber yang sama, yaitu perbandingan harga pasar. Metode penilaian yang digunakan pada penelitian ini adalah penilaian masal karena lokasi penelitian yang luas.

NJOP yang berlaku seharusnya sesuai dengan harga pasar yang ada saat ini. Namun, besaran NJOP biasanya hanya $50 \%$ dari harga pasar (Situmorang, et.al., 2015). NJOP yang tidak sesuai dengan harga pasar menyebabkan NJOP yang seharusnya dapat mewakili nilai tanah, tidak dapat mewakili nilai tanah dalam suatu zona tertentu. Maka dari itu NJOP yang didapatkan dari harga pasar akan menaikkan nilai PBB dan BPHTB sehingga meningkatkan pula nilai Pendapatan Asli Daerah (Satria, 2014). Hal ini semakin mendasari berkembangnya pembuatan Peta Zona Nilai Tanah (ZNT) dalam sistem penilaian nilai tanah saat ini.

\section{METODE}

Lokasi penelitian ini mengambil studi di Kecamatan Rungkut Kota Surabaya yang secara geografis terletak pada $7^{\circ} 18^{\prime} 30^{\prime \prime}$ LS $7^{\circ} 19^{\prime} 49^{\prime \prime}$ LS dan $112^{\circ} 45^{\prime} 27^{\prime \prime}$ BT - 112 $50^{\circ} 44^{\prime \prime}$ BT. Kecamatan Rungkut terdiri dari enam kelurahan, yaitu Kelurahan Kedung Baruk, Kelurahan Medokan Ayu, Kelurahan Kalirungkut, Kelurahan Penjaringan Sari, dan Kelurahan Rungkut Kidul.

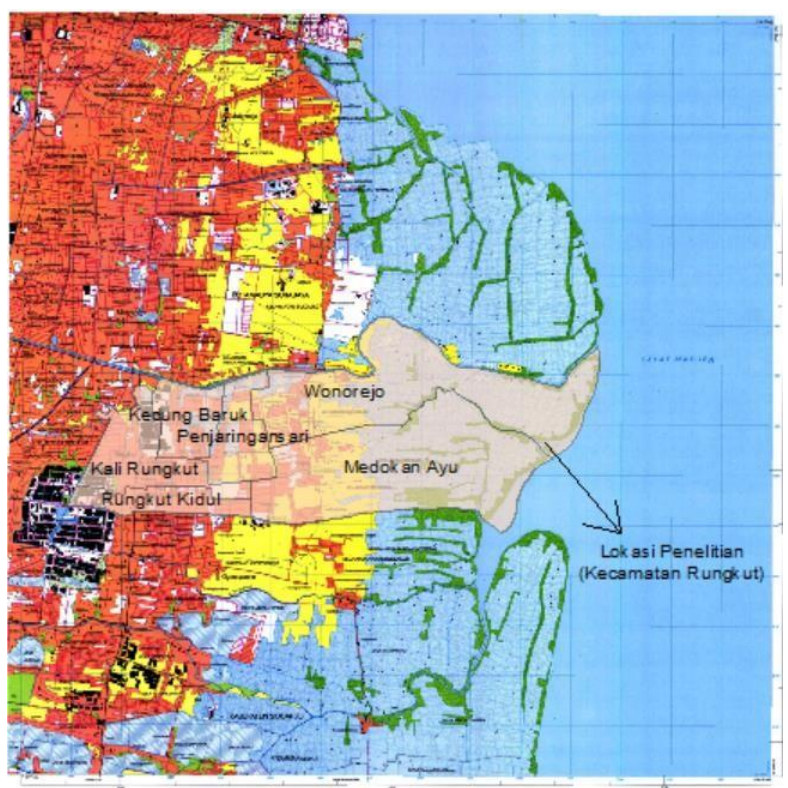

Gambar 1. Lokasi Penelitian

Data yang digunakan dalam penelitian ini meliputi Peta Rencana Detail Tata Ruang Kecamatan Rungkut tahun 2018 - 2038, Foto udara Kota Surabaya tahun 2016, Harga tanah bulan Maret tahun 2019 dan NJOP Kecamatan Rungkut tahun 2018.

Proses pengolahan data dimulai dari proses cropping antara foto udara Kota Surabaya dengan batas administrasi Kecamatan Rungkut untuk memperoleh Peta Administrasi Kecamatan Rungkut yang selanjutnya digunakan dalam pembuatan deliniasi zona awal. Pembuatan deliniasi zona awal dilakukan berdasarkan karakteristik zona yang sama seperti jenis penggunaan lahan, kontur, bentuk, kedudukan tanah, dan aksessibilitas jalan.

Pelaksanaan survei harga pasar dengan mencari minimal 3 sampel data pada tiap zona sesuai dengan ketentuan dari Surat Edaran Direktur Jenderal Pajak Nomor: SE25/PJ.6/2006. Harga pasar yang diperoleh dilakukan penyesuaian data untuk memperoleh nilai tanah yang dapat digunakan dalam pembuatan zona nilai tanah.

Perhitungan Nilai Indeks Rata-Rata (NIR) dilakukan dengan melakukan rerata dari 3 sampel tanah pada tiap zona. Kemudian NIR yang didapatkan diklasifikasikan terhadap 
kelas NJOP Kota Surabaya. Selanjutnya dibuatlah Peta ZNT Tahun 2019.

Penggabungan Peta NJOP Tahun 2018 dan Peta ZNT Tahun 2019 masing-masing terhadap Peta RDTR Kecamatan Rungkut untuk memperoleh perpotongan antar zona yang digunakan dalam perhitungan potensi PBB dan BPHTB dengan mengalikan luas zona terhadap NJOP.

\section{HASIL DAN PEMBAHASAN}

\section{Deliniasi Zona}

Pembuatan deliniasi zona awal dilakukan berdasarkan karakteristik zona yang sama seperti jenis penggunaan lahan, kontur, bentuk, kedudukan tanah, dan aksessibilitas jalan. Deliniasi zona awal dilakukan untuk mempermudah pengambilan sampel data saat melakukan survei lapangan Sebaran sampel data informasi harga tanah sebanyak 144 data yang didapatkan dari survei lapangan pada bulan Maret tahun 2019 dapat dilihat pada Gambar 2.

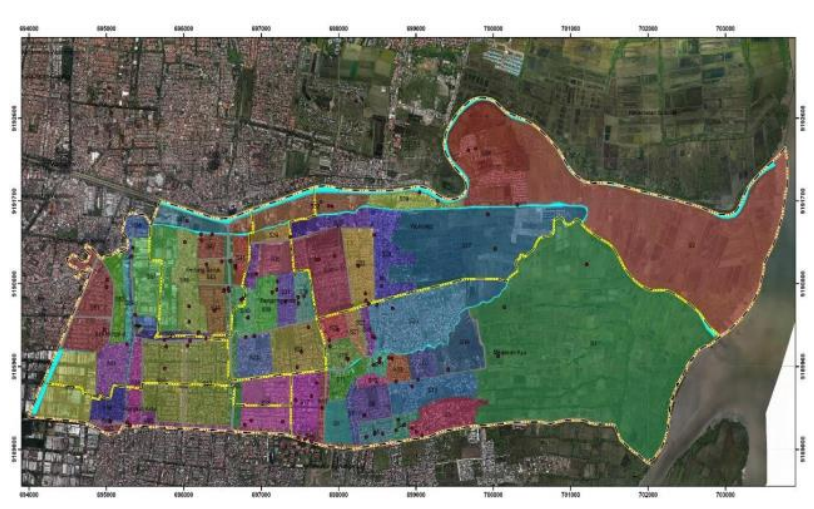

Gambar 2. Peta Deliniasi Zona Awal

\section{Hasil Perhitungan NIR}

Data informasi harga tanah yang didapatkan dari survei lapangan memerlukan penyesuaian data untuk memperoleh nilai tanah yang dapat digunakan dalam pembuatan zona nilai tanah (MAPPI, 2018). Tabel 1 di bawah ini merupakan hasil perhitungan NIR di Kecamatan Rungkut.
Tabel 1. Perhitungan Nilai Indikasi Rata - Rata

\begin{tabular}{|c|c|c|c|c|}
\hline No & $\begin{array}{l}\text { Point } \\
\text { Code }\end{array}$ & $\begin{array}{l}\text { Zone } \\
\text { Code }\end{array}$ & $\begin{array}{c}N I R \\
\left(R p / m^{2}\right)\end{array}$ & Subdistrict \\
\hline 1 & $\begin{array}{l}\text { SA198 } \\
\text { SA191 } \\
\text { SA188 }\end{array}$ & S1 & 1.007 .837 & $\begin{array}{c}\text { Medokan } \\
\text { Ayu }\end{array}$ \\
\hline 2 & $\begin{array}{l}\text { SA46 } \\
\text { SA47 } \\
\text { SA48 } \\
\end{array}$ & S13 & 4.444 .790 & $\begin{array}{l}\text { Medokan } \\
\text { Ayu }\end{array}$ \\
\hline 3 & $\begin{array}{l}\text { SA119 } \\
\text { SA120 } \\
\text { SA121 }\end{array}$ & S33 & 15.190 .604 & $\begin{array}{c}\text { Penjaringan } \\
\text { sari }\end{array}$ \\
\hline 4 & $\begin{array}{l}\text { SA92 } \\
\text { SA93 } \\
\text { SA94 }\end{array}$ & S46 & 32.486 .242 & $\begin{array}{l}\text { Rungkut } \\
\text { Kidul }\end{array}$ \\
\hline 5 & $\begin{array}{l}\text { SA149 } \\
\text { SA150 } \\
\text { SA124 }\end{array}$ & S65 & 41.448 .823 & $\begin{array}{c}\text { Kedung } \\
\text { Baruk, } \\
\text { Penjaringan } \\
\text { sari }\end{array}$ \\
\hline
\end{tabular}

\section{Peta Zona Nilai Tanah 2019}

Peta Zona Nilai Tanah (ZNT) adalah area yang menggambarkan nilai tanah yang relatif sama (Deviantari, et. Al., 2016). Dalam pembuatannya, ZNT memerlukan minimal tiga sampel harga tanah pada tiap zona untuk menghitung Nilai Indeks Rata-Rata (NIR). Berdasarkan Peraturan Menteri Keuangan Nomor 150/PMK.03/2010 tentang NJOP, ZNT yang sudah dilakukan deliniasi zona awal selanjutnya dikelompokkan sesuai dengan NJOP yang berlaku. Berikut ini adalah hasil pembuatan Peta ZNT Tahun 2019.

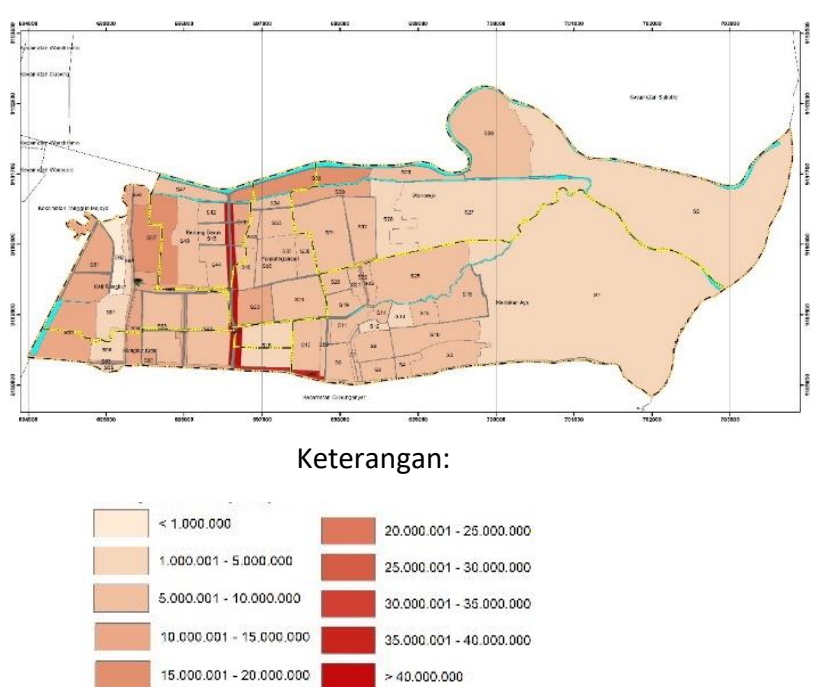

Gambar 3. Peta Zona Nilai Tanah 2019 


\section{Kesesuaian Penggunaan Lahan antara Zona Nilai Tanah dan Rencana Tata Ruang}

Berdasarkan Peraturan Menteri Agraria dan Tata Ruang/Badan Pertanahan Nasional Tahun 2018 Tentang Pedoman Penyusunan Rencana Detail Tata Ruang dan Peraturan Zonasi Kabupaten/Kota pasal 5 ayat 1 yang menyatakan bahwa RDTR berlaku dalam jangka waktu 20 (dua puluh) tahun dan ditinjau kembali setiap 5 (lima) tahun. Oleh karena itu dibutuhkan waktu dalam penyesuaian lahan terhadap rencana tata ruang suatu wilayah. Beberapa macam jenis penggunaan tanah dalam RDTR yang dimungkinkan untuk diperoleh PAD yaitu perdagangan dan jasa, industri, permukiman, serta perkantoran.

Tabel 2. Penggunaan Lahan Zona Nilai Lahan terhadap Rencana Tata Ruang (Industri)

\begin{tabular}{llll}
\hline No & $\begin{array}{c}\text { Jenis } \\
\text { Penggunaan }\end{array}$ & \multicolumn{1}{c}{ Luas $\left(\mathbf{m}^{\mathbf{2}}\right)$} & Persentase \\
\hline 1 & Industri & $864.125,849$ & $99,22 \%$ \\
\hline 2 & Perumahan & $2.921,248$ & $0,34 \%$ \\
\hline 3 & Permukiman & $1.926,835$ & $0,22 \%$ \\
\hline 4 & Komersil & $1.964,112$ & $0,23 \%$ \\
\hline & Total & $870.938,045$ & $100 \%$ \\
\hline
\end{tabular}

Kesesuaian lahan industri pada ZNT yang ditunjukkan pada tabel 2 sebesar $864.125,849 \mathrm{~m}^{2}$ dari total penggunaan industri sebesar 870.938,045 $\mathrm{m}^{2}$ maka kesesuaian penggunaan lahan industri diperoleh presentase sebesar $99,22 \%$.

Tabel 3. Penggunaan Lahan Zona Nilai Tanah Terhadap Rencana Tata Ruang (Perdagangan)

\begin{tabular}{llll}
\hline No & $\begin{array}{c}\text { Jenis } \\
\text { Penggunaan }\end{array}$ & \multicolumn{1}{c}{ Luas $\left(\mathbf{m}^{\mathbf{2}} \mathbf{}\right.$} & Persentase \\
\hline 1 & Industri & $40.688,540$ & $2,07 \%$ \\
\hline 2 & Perumahan & $1051.935,928$ & $53,59 \%$ \\
\hline 3 & Permukiman & $350.261,457$ & $17,84 \%$ \\
\hline 4 & Komersil & $424.020,632$ & $21,60 \%$ \\
\hline 5 & Tambak & $90.412,451$ & $4,61 \%$ \\
\hline 6 & $\begin{array}{l}\text { Sarana } \\
\text { Pelayanan } \\
\end{array}$ & $5.625,424$ & $0,29 \%$ \\
\hline & & \\
\hline & Total & $1.962 .944,432$ & $100 \%$ \\
\hline
\end{tabular}

Kesesuaian penggunaan lahan komersil dengan perdagangan dan jasa yang ditunjukkan pada tabel 3 diperoleh sebesar 424.020,632 $\mathrm{m}^{2}$ dari total 1.962.944,432 $\mathrm{m}^{2}$. Hal tersebut menunjukkan bahwa kemajuan pembangunan daerah perdagangan dan jasa hanya sebesar $21,60 \%$ sedangkan $53,59 \%$ persentase terbesar dimiliki oleh perumahan.

Tabel 4. Penggunaan Lahan Zona Nilai Lahan Terhadap Rencana Tata Ruang (Kantor)

\begin{tabular}{clll}
\hline No & Jenis Penggunaan & Luas $\left(\mathbf{m}^{\mathbf{2}}\right)$ & Persentase \\
\hline 1 & Perumahan & $11.399,98$ & $38,62 \%$ \\
\hline 2 & Permukiman & $18.045,51$ & $61,14 \%$ \\
\hline 3 & Komersil & 71,43 & $0,24 \%$ \\
\hline & Total & $29.516,92$ & $100 \%$ \\
\hline
\end{tabular}

Kesesuaian penggunaan lahan komersil dengan perkantoran yang ditunjukkan pada tabel 4 diperoleh sebesar $71,432 \mathrm{~m}^{2}$ dari total $29.516,92 \mathrm{~m}^{2}$. Hal tersebut menunjukkan bahwa kemajuan pembangunan daerah perkantoran hanya sebesar $0,24 \%$ sedangkan $38,62 \%$ persentase terbesar dimiliki oleh perumahan dan permukiman sebesar $61,14 \%$.

Tabel 5. Penggunaan Lahan Zona Nilai Tanah

Terhadap Rencana Tata Ruang (Perumahan)

\begin{tabular}{clrr}
\hline No & Jenis Penggunaan & Luas $\left(\mathbf{m}^{\mathbf{2}}\right)$ & Persentase \\
\hline 1 & Industri & $36.292,1$ & $0,40 \%$ \\
\hline 2 & Perumahan & $3.675 .778,3$ & $40,23 \%$ \\
\hline 3 & Permukiman & $4.075 .033,9$ & $44,60 \%$ \\
\hline 4 & Komersil & $145.472,6$ & $1,59 \%$ \\
\hline 5 & Tambak & $1.187 .962,3$ & $13 \%$ \\
\hline 6 & Sarana Pelayanan & $15.469,7$ & $0,17 \%$ \\
& Umum & $9.136 .008,5$ & $100 \%$ \\
\hline & Total &
\end{tabular}

Kesesuaian penggunaan lahan permukiman dan perumahan dengan permukiman yang ditunjukkan pada tabel 5 diperoleh masing-masing sebesar 4.075.033,9 $\mathrm{m}^{2}$ dan 36.292,122 $\mathrm{m}^{2}$ dari total $29.516,92 \mathrm{~m}^{2}$. Hal tersebut menunjukkan bahwa kemajuan pembangunan daerah permukiman sudah mencapai $84,83 \%$.

Hasil Perhitungan Pendapatan Daerah Terhadap Rencana Tata Ruang

Pendapatan Asli Daerah dalam penelitian ini difokuskan pada potensi penerimaan PBB dan BPHTB yang dihitung berdasarkan NJOP per meter suatu zona dikalikan dengan luas zona tersebut. Adapun formula perhitungan PBB dan BPHTB di Kota Surabaya (Walikota Surabaya, 2010\&2011), yaitu:

$$
\mathrm{PBB}=0,1 \% \text { (NJOP }- \text { NJOPTKP) }
$$




$$
\text { BPHTB }=5 \%(\text { NPOP }- \text { NPOPTKP })
$$

Tabel 6. Hasil Hasil Perhitungan PAD dari NJOP 2018

\begin{tabular}{llrr}
\hline No & \multicolumn{1}{c}{$\begin{array}{c}\text { Jenis } \\
\text { Penggunaan } \\
\text { RDTR }\end{array}$} & $\begin{array}{c}\text { Potensi PBB } \\
\text { (Rp) }\end{array}$ & $\begin{array}{c}\text { Potensi BPHTB } \\
\text { (Rp) }\end{array}$ \\
\hline 1 & Industri & 343.956 .460 & 171.951 .229 .763 \\
\hline 2 & $\begin{array}{l}\text { Perdagangan dan } \\
\text { Jasa }\end{array}$ & 783.948 .622 & 391.902 .311 .108 \\
\hline 3 & Perkantoran & 16.176 .257 & 8.064 .128 .540 \\
\hline 4 & Permukiman & 2.277 .494 .806 & 1.138 .669 .402 .846 \\
\hline
\end{tabular}

Tabel 7. Hasil Perhitungan PAD dari ZNT 2019

\begin{tabular}{ccrr}
\hline No & $\begin{array}{c}\text { Jenis } \\
\text { Penggunaan } \\
\text { RDTR }\end{array}$ & $\begin{array}{c}\text { Potensi PBB } \\
\text { (Rp) }\end{array}$ & \multicolumn{1}{c}{$\begin{array}{c}\text { Potensi BPHTB } \\
\text { (Rp) }\end{array}$} \\
\hline 1 & Industri & 1.273 .270 .852 & 636.614 .426 .175 \\
\hline 2 & $\begin{array}{l}\text { Perdagangan } \\
\text { dan Jasa }\end{array}$ & 2.292 .819 .843 & 1.146 .244 .921 .292 \\
\hline 3 & Perkantoran & 26.114 .024 & 13.039 .012 .221 \\
\hline 4 & Permukiman & 6.182 .545 .594 & 3.091 .080 .796 .943 \\
\hline
\end{tabular}

Tabel 8. Potensi Peningkatan PAD

\begin{tabular}{clcr}
\hline No & $\begin{array}{c}\text { Jenis } \\
\text { Penggunaan } \\
\text { RDTR }\end{array}$ & $\begin{array}{c}\text { Potensi } \\
\text { PBB }\end{array}$ & $\begin{array}{c}\text { Potensi } \\
\text { BPHTB }\end{array}$ \\
\hline 1 & Industri & $270 \%$ & $270 \%$ \\
\hline 2 & $\begin{array}{l}\text { Perdagangan } \\
\text { dan Jasa }\end{array}$ & $192 \%$ & $192 \%$ \\
\hline 3 & Perkantoran & $61 \%$ & $62 \%$ \\
\hline 4 & Permukiman & $171 \%$ & $171 \%$ \\
\hline
\end{tabular}

Peningkatan potensi penerimaan PAD melalui PBB dan BPTHB yang ditunjukkan pada tabel 8 didapatkan dari perbandingan ZNT tahun 2019 terhadap NJOP tahun 2018. Hasil yang didapatkan bernilai sama antara PBB dan BPHTB dikarenakan pada saat melakukan perhitungan tidak dikalikan terhadap banyaknya jumlah persil tanah di Kecamatan Rungkut.

Potensi peningkatan PAD tertinggi pada PBB dimiliki oleh zona industri sebesar $270 \%$ dari Rp343.956.460,00 tahun 2018 menjadi Rp1.273.270.852,00 pada tahun 2019 yang dapat dilihat pada tabel 6 dan 7 sedangkan potensi peningkatan PBB terendah dimiliki oleh zona perkantoran dengan nilai potensi sebesar $61 \%$ dari Rp16.176.257,00 pada tahun 2018 menjadi Rp26.114.024,00 pada tahun 2019. Zona industri memiliki peningkatan tertinggi karena adanya perbedaan NJOP yang signifikan antara NJOP tahun 2018 dan ZNT tahun 2019. Zona perkantoran memiliki potensi terkecil dikarenakan zona permukiman mendominasi daerah yang nantinya dijadikan zona perkantoran dengan luas sebesar 18.045,51 m2 dari total luas perkantoran sebesar 29.516,92 $\mathrm{m} 2$ dengan persentase sebesar $61,14 \%$. Nilai tanah pada zona permukiman merupakan yang terendah diantara jenis penggunaan tanah dalam RDTR yang dimungkinkan untuk diperoleh PAD.

\section{KESIMPULAN}

Kesimpulan yang diperoleh dari penelitian ini adalah sebagai berikut:

1. Kesesuaian lahan tertinggi mencapai 99,22\% dimiliki oleh zona industri dengan luasan sebesar $857121,718 \mathrm{~m} 2$ dari total luas zona industri sebesar $862047.715 \mathrm{~m} 2$ sedangkan kesesuaian terendah dimiliki oleh zona perkantoran sebesar $0,24 \%$ dengan luas $71,43 \mathrm{~m}$ dari total luas zona perkantoran sebesar 29.516,92.

2. Peningkatan Potensi PAD terhadap RDTR melalui PBB dan BPHTB yang didapatkan dari perbandingan ZNT tahun 2019 terhadap NJOP tahun 2018 menunjukkan nilai yang positif atau meningkat. Potensi peningkatan PAD tertinggi melalui PBB dimiliki oleh zona industri dengan nilai 270\% dari Rp340.386.549,00 di tahun 2018 menjadi Rp1.260.854.849.00 pada tahun 2019 sedangkan potensi peningkatan PBB terendah dimiliki oleh zona perkantoran dengan nilai potensi sebesar $61 \%$ dari Rp16.176.257,00 pada tahun 2018 menjadi Rp26.114.024,00 pada tahun 2019.

\section{DAFTAR PUSTAKA}

Deviantari, U. W., Budisusanto, Y., \& Arafah, F. 2016. Pembuatan Peta Zona Nilai Tanah Untuk Mengetahui Perubahan Nilai Tanah di Kecamatan Rungkut. GEOID, 11(2), 122132.

Satrio, H. 2014. Detik Properti. Diambil kembali dari Detik Finance:https://finance.detik.com/ properti/d-2520654/besaran-njopbiasanya-hanya-50-dari-harga- pasar

Situmorang, S. A., Subiyanto, S., \& Awaluddin, M. 2015. Pembuatan Peta Zona Nilai Tanah Berdasarkan Harga Pasar untuk 
Menentukan Nilai Jual Objek Pajak di

Kecamatan Gajah Mungkur Kota Semarang. Jurnal Geodesi UNDIP, 4(4), 9198.

MAPPI. 2018. Kode Etik Penilai Indonesia dan Standar Penilaian Indonesia Edisi VII. Jakarta: MAPPI.

Walikota Surabaya. 2010. Peraturan Daerah Kota Surabaya Nomor 10 Tahun 2010 Tentang Pajak Bumi dan Bangunan Kota Perkotaan. Surabaya: Pemerintah Kota Surabaya.

Walikota Surabaya. 2010. Peraturan Daerah Kota Surabaya Nomor 11 Tahun 2010 Tentang Bea Perolehan Hak Atas Tanah dan Bangunan. Surabaya: Pemerintah Kota Surabaya. 